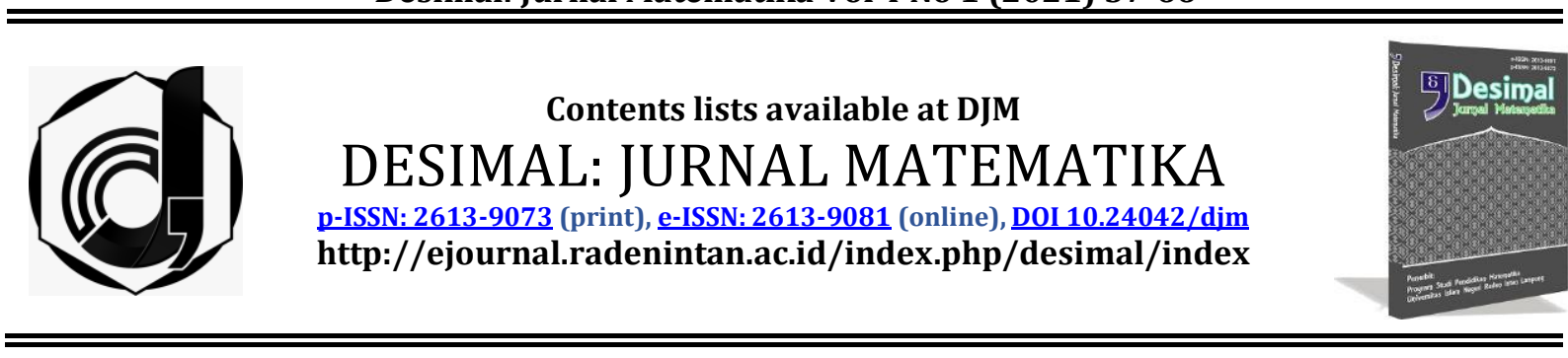

\title{
Integer linear programming application in production results optimization using cutting plane method
}

\author{
Fery Firmansah*, Fitriana Wulandari \\ Universitas Widya Dharma Klaten, Indonesia
}

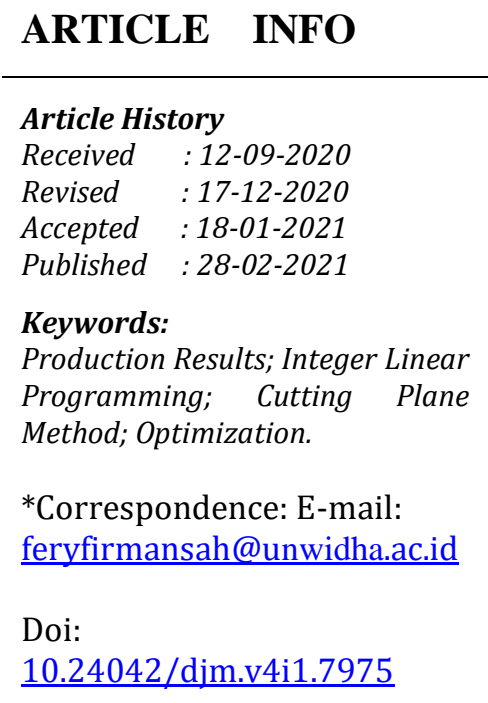

\begin{abstract}
Integer Linear Programming is a special form of linear programming which the decision variables are in integer form. Berkah Rasa is a home industry business in the form of Jenang Ayu and Jenang Krasikan processed food. The daily production that carried out by Berkah Rasa is based on the availability of raw materials and the number of requests. So far, Berkah Rasa has not had the right strategy in producing Jenang to get maximum profit. The purpose of this research is to apply integer linear programming to the optimization of Jenang Ayu and Jenang Krasikan production. The method used to solve this problem is the cutting plane method. The results of the research obtained is the optimal solution for Berkah Rasa, that is by producing $25 \mathrm{~kg}$ of Jenang Ayu and $22 \mathrm{~kg}$ of Jenang Krasikan every day. So that the benefits obtained by Berkah Rasa every day are IDR 727,000.00.
\end{abstract}

http://ejournal.radenintan.ac.id/index.php/desimal/index

\section{INTRODUCTION}

Linear program is a mathematical model to get the best alternative use of available resources (Aminudin, 2005). Linear program is often used in solving resource allocation problems. In some cases, the decision variables must be integers (Sitorus, 1997). Integer Linear Programming is linear programs in which some or all of the decision variables are an integer value. One of the methods used to solve integer programs is by using the cutting plane method. The cutting plane method is a method used to solve integer linear programming problems, both pure and mixed integers by adding a number of new constraints (Siang, 2011).

The cutting plane method was developed to find the optimum solution for integer program. This method is carried out by adding a constraint called the Gomory constraint. The addition of the Gomory constraints is done in the optimal table so that it can shorten the calculation (Siagian, 2006). The completion of the integer program using the cutting plane method must be done using the simplex 
method because the iteration requires new constraints formed from the fractional component of the slack variable (Siang, 2011).

The cutting plane method algorithm is as follows: The first step is solving a mathematical model using the simplex method. The second step is if you get an integer solution, then the process is complete. However, if the solution obtained is a fraction. Then choose any simplex optimal row which in the right side of the column contains a fraction. The equation formed in that line is

$$
\sum_{j} a_{i j} x_{j}=b_{i}
$$

The third step adds a new constraint with

$$
\sum_{j} f_{i j} x_{j} \geq f_{i}
$$

to the initial problem with

$$
\begin{aligned}
& f_{i j}=\text { fractional part in } a_{i j} \\
& f_{i}=\text { fractional part in } b_{i} \\
& \text { The fourth step is returns to the first }
\end{aligned}
$$
step.

Research on integer programs has been discussed previously, among others. Nico et al. (2014) used the cutting plane method in optimizing the annual production amount at PT YXZ. Basriati (2018) used integer linear programming with the cutting plane method approach and the branch and bound method for optimization of tofu production. Alfian (2019) has used a linear integer programming model to optimize the production planning at UKM. Other relevant research is provided in Basriati et al. (2018), Dey \& Richard (2009), and Pätzold \& Schöbel (2020).

In line with the relevant research, the author has succeeded in developing an integer linear programming application to optimize the production of Berkah Rasa using the cutting plane method. The results of this research are proven to be able to get the application of mathematics closer to everyday life, especially in the home industry business.

\section{METHOD}

This research is an applied research which aims to provide practically solutions to certain problems in everyday life. The data in this study is primary data which are collected by the researcher directly from the place of research object and the source of the data is obtained from the research location, that is Berkah Rasa in Pendem Hamlet, Wonosari Village, Trucuk District, Klaten Regency. Where each production result is influenced by the availability of raw materials, the amount of demand, and profit.

The following data is obtained from Berkah Rasa. Data of raw materials per day for every $1 \mathrm{~kg}$ of product, data of the number of requests per day, and data of profit per $1 \mathrm{~kg}$ of product. The raw materials used per day are $21 \mathrm{~kg}$ of glutinous rice, $22 \mathrm{~kg}$ of palm sugar, and 25.7 liters of coconut milk. Every $1 \mathrm{~kg}$ of Jenang Ayu requires 400 grams of glutinous rice, 500 grams of palm sugar, and $500 \mathrm{ml}$ of coconut milk with a profit of IDR 15,000 / kg. Meanwhile, every $1 \mathrm{~kg}$ of Jenang Krasikan requires 500 grams of glutinous rice, 400 grams of palm sugar, and $600 \mathrm{ml}$ of coconut milk with a profit of IDR $16,000 / \mathrm{kg}$. The minimum number of requests per day for Jenang Ayu is $20 \mathrm{~kg}$ and Jenang Krasikan is $15 \mathrm{~kg}$.

The data analysis steps used in this research are modeling the optimization problem of the production of Jenang Ayu and Jenang Krasikan at Berkah Rasa into a linear programming model, then solve the linear programming model using the cutting plane method. The decision variables obtained are integers. So, the optimal amount of the production and the amount of profit obtained can be found. 
Desimal, 4 (1), 2021 - 59

Fery Firmansah, Fitriana Wulandari

\section{RESULTS AND DISCUSSION}

Modeling the optimization problem of the production of Jenang Ayu and Jenang Krasikan into a linear program.

\section{The Decision Variables}

The products to be optimized are Jenang Ayu and Jenang Krasikan at Berkah Rasa, so that the following decision variables can be formed.

$x_{1}=$ the number of Jenang Ayu produced / day (kg)

$x_{2}=$ the number of Jenang Krasikan produced / day (kg)

\section{The Objective Function}

The objective function in this research is maximize the profit from each production of Jenang Ayu and Jenang Krasikan.

Table 1. The Profit of Berkah Rasa Production

\begin{tabular}{cc}
\hline The type of Jenang & Profits (IDR) \\
Jenang Ayu & 15000 \\
Jenang Krasikan & 16000 \\
\hline
\end{tabular}

The profit from each product shows the coefficient of each decision variable. The objective function for the production of Jenang at Berkah Rasa is

Maximize $z=15000 x_{1}+16000 x_{2}$ or Maximize $z=15 x_{1}+16 x_{2}$ (Thousands)

\section{The Constraint Function}

The constraint function is a set of constraints that must be considered in determining the decision variables. In a production, these constraints are usually referred to as obstacles or limitations. In this research, Berkah Rasa has limitations in the availability of materials and the number of requests.
Table 2. Raw Materials and Availability

\begin{tabular}{cccc}
\hline \multirow{2}{*}{$\begin{array}{c}\text { The type of } \\
\text { Jenang }\end{array}$} & $\begin{array}{c}\text { Glutinous } \\
\text { rice } \\
\text { (gram) }\end{array}$ & $\begin{array}{c}\text { Palm } \\
\text { Sugar } \\
\text { (gram) }\end{array}$ & $\begin{array}{c}\text { Coconut } \\
\text { Milk } \\
\text { (ml) }\end{array}$ \\
$\begin{array}{c}\text { Jenang } \\
\text { Ayu }\end{array}$ & 400 & 500 & 500 \\
$\begin{array}{c}\text { Jenang } \\
\text { Krasikan }\end{array}$ & 500 & 400 & 600 \\
Availability & 21000 & 22000 & 25700 \\
\hline
\end{tabular}

From Table 2, the constraint function can be formulated as follows. Glutinous rice: $400 x_{1}+500 x_{2} \leq 21000$ $\Leftrightarrow 4 x_{1}+5 x_{2} \leq 210$

Palm Sugar : $: 500 x_{1}+400 x_{2} \leq 22000$

$\Leftrightarrow 5 x_{1}+4 x_{2} \leq 220$

Coconut Milk : $500 x_{1}+600 x_{2} \leq 25700$

$\Leftrightarrow 5 x_{1}+6 x_{2} \leq 257$

Table 3. The Amount of Requests

\begin{tabular}{cc}
\hline $\begin{array}{c}\text { The type of } \\
\text { Jenang }\end{array}$ & Requests \\
Jenang Ayu & 20 \\
Jenang Krasikan & 15 \\
\hline
\end{tabular}

From Table 3, the constraint function can be formulated as follows.

$$
\begin{aligned}
& x_{1} \geq 20 \\
& x_{2} \geq 15
\end{aligned}
$$

\section{Linear Programming Modal}

The general form of a linear programming on the optimization problem of the production of Jenang at Berkah Rasa is as follows.

Maximize :

$z=15 x_{1}+16 x_{2}$ (Thousands)

Constraints :

$4 x_{1}+5 x_{2} \leq 210$

$5 x_{1}+4 x_{2} \leq 220$

$5 x_{1}+6 x_{2} \leq 257$

$x_{1} \geq 20$

$x_{2} \geq 15$

$x_{1}, x_{2} \geq 0$ 
Desimal, 4 (1), 2021 - 60

Fery Firmansah, Fitriana Wulandari

Completing the linear programming model that has been obtained using the cutting plane method.

The first step is solving the mathematical model using the simplex method. Converting the mathematical model into a standard simplex form. The standard form of simplex on the optimization problem of the production of Jenang at Berkah Rasa is as follows.

\section{Program-1}

Maximize :

$z=15 x_{1}+16 x_{2}+0 x_{3}+0 x_{4}+0 x_{5}+$

$0 x_{6}+0 x_{7}-M x_{8}-M x_{9}$ (Thousands)

Constraints :

$4 x_{1}+5 x_{2}+x_{3}=210$

$5 x_{1}+4 x_{2}+x_{4}=220$

$5 x_{1}+6 x_{2}+x_{5}=257$

$$
\begin{aligned}
& x_{1}-x_{6}+x_{8}=20 \\
& x_{2}-x_{7}+x_{9}=15 \\
& x_{1}, \ldots, x_{9} \geq 0
\end{aligned}
$$

From the calculations in Table 4 using the simplex method, the solution for $x_{1}=\frac{146}{5}=29,2$ and $x_{2}=\frac{37}{2}=18,5$ is obtained with the value of $z=734$ (Thousands). Since the result is not an integer yet, then choose any optimal simplex row in the column on the right side that containing the fraction. Then add the constraint $\frac{3}{5} x_{4}+\frac{3}{5} x_{5} \geq \frac{1}{5}$ into the next program. If it is interpreted geometrically using substitution and elimination, the constraint $\frac{3}{5} x_{4}+\frac{3}{5} x_{5} \geq \frac{1}{5}$ will equal to $3 x_{1}+3 x_{2} \leq 143$. 
Desimal, 4 (1), 2021 - 61

Fery Firmansah, Fitriana Wulandari

Table 4. Simplex Solution for Program-1

\begin{tabular}{|c|c|c|c|c|c|c|c|c|c|c|c|c|}
\hline$\left(c_{B}\right)_{i}$ & ${ }_{\left(x_{B}\right)_{i}}^{c_{j}}$ & $\begin{array}{l}15 \\
x_{1}\end{array}$ & $\begin{array}{l}16 \\
x_{2}\end{array}$ & $\begin{array}{r}0 \\
x_{3}\end{array}$ & $\begin{array}{r}0 \\
x_{4}\end{array}$ & $\begin{array}{r}0 \\
x_{5}\end{array}$ & $\begin{array}{c}0 \\
x_{6}\end{array}$ & $\begin{array}{c}0 \\
x_{7}\end{array}$ & $\begin{array}{c}-M \\
x_{8}\end{array}$ & $\begin{array}{c}-M \\
x_{9}\end{array}$ & $b_{i}$ & $\boldsymbol{\theta}$ \\
\hline 0 & $x_{3}$ & 4 & 5 & 1 & 0 & 0 & 0 & 0 & 0 & 0 & 210 & 42 \\
\hline 0 & $x_{4}$ & 5 & 4 & 0 & 1 & 0 & 0 & 0 & 0 & 0 & 220 & 55 \\
\hline 0 & $x_{5}$ & 5 & 6 & 0 & 0 & 1 & 0 & 0 & 0 & 0 & 257 & $\frac{257}{6}$ \\
\hline$-M$ & $x_{8}$ & 1 & 0 & 0 & 0 & 0 & -1 & 0 & 1 & 0 & 20 & $\begin{array}{l}6 \\
-\end{array}$ \\
\hline \multirow[t]{2}{*}{$-M$} & $x_{9}$ & 0 & 1 & 0 & 0 & 0 & 0 & -1 & 0 & 1 & 15 & 15 \\
\hline & $\begin{array}{c}z_{j} \\
c_{j}-z_{j}\end{array}$ & $\begin{array}{l}-M \\
M+15\end{array}$ & $\begin{array}{l}-M \\
M+16\end{array}$ & $\begin{array}{l}0 \\
0\end{array}$ & $\begin{array}{l}0 \\
0\end{array}$ & $\begin{array}{l}0 \\
0\end{array}$ & $\begin{array}{c}M \\
-M\end{array}$ & $\begin{array}{c}M \\
-M\end{array}$ & $\begin{array}{c}-M \\
0\end{array}$ & $\begin{array}{c}-M \\
0\end{array}$ & $-35 M$ & \\
\hline 0 & $x_{3}$ & 4 & 0 & 1 & 0 & 0 & 0 & 5 & 0 & -5 & 135 & $\frac{135}{4}$ \\
\hline 0 & $x_{4}$ & 5 & 0 & 0 & 1 & 0 & 0 & 4 & 0 & -4 & 160 & 32 \\
\hline 0 & $x_{5}$ & 5 & 0 & 0 & 0 & 1 & 0 & 6 & 0 & -6 & 167 & $\frac{167}{5}$ \\
\hline$-M$ & $x_{8}$ & 1 & 0 & 0 & 0 & 0 & -1 & 0 & 1 & 0 & 20 & 20 \\
\hline \multirow[t]{3}{*}{16} & $x_{2}$ & 0 & 1 & 0 & 0 & 0 & 0 & -1 & 0 & 1 & 15 & - \\
\hline & $z_{j}$ & $-M$ & 16 & 0 & 0 & 0 & $M$ & -16 & $-M$ & 16 & $-20 M+$ & \\
\hline & $c_{j}-z_{j}$ & $M+15$ & 0 & 0 & 0 & 0 & $-M$ & 16 & 0 & $-M-16$ & 240 & \\
\hline 0 & $x_{3}$ & 0 & 0 & 1 & 0 & 0 & 4 & 5 & -4 & -5 & 55 & 11 \\
\hline 0 & $x_{4}$ & 0 & 0 & 0 & 1 & 0 & 5 & 4 & -5 & -4 & 60 & 15 \\
\hline 0 & $x_{5}$ & 0 & 0 & 0 & 0 & 1 & 5 & 6 & -5 & -6 & 67 & $\frac{67}{6}$ \\
\hline 15 & $x_{1}$ & 1 & 0 & 0 & 0 & 0 & -1 & 0 & 1 & 0 & 20 & - \\
\hline \multirow[t]{3}{*}{16} & $x_{2}$ & 0 & 1 & 0 & 0 & 0 & 0 & -1 & 0 & 1 & 15 & - \\
\hline & $z_{j}$ & 15 & 16 & 0 & 0 & 0 & -15 & -16 & 15 & 16 & & \\
\hline & $c_{j}-z_{j}$ & 0 & 0 & 0 & 0 & 0 & 15 & 16 & $\begin{array}{c}-M- \\
15\end{array}$ & $-M-16$ & 540 & \\
\hline 0 & $x_{7}$ & 0 & 0 & $\frac{1}{5}$ & 0 & 0 & $\frac{4}{5}$ & 1 & $-\frac{4}{5}$ & -1 & 11 & $\frac{55}{4}$ \\
\hline 0 & $x_{4}$ & 0 & 0 & $\begin{array}{r}5 \\
-\frac{4}{5}\end{array}$ & 1 & 0 & $\begin{array}{l}5 \\
\frac{9}{5}\end{array}$ & 0 & $\begin{array}{r}5 \\
-\frac{9}{5}\end{array}$ & 0 & 16 & $\begin{array}{l}\frac{40}{9} \\
\frac{1}{9}\end{array}$ \\
\hline 0 & $x_{5}$ & 0 & 0 & $-\frac{6}{5}$ & 0 & 1 & $\frac{1}{5}$ & 0 & $-\frac{1}{5}$ & 0 & 1 & 5 \\
\hline 15 & $x_{1}$ & 1 & 0 & 0 & 0 & 0 & -1 & 0 & 1 & 0 & 20 & - \\
\hline \multirow[t]{3}{*}{16} & $x_{2}$ & 0 & 1 & $\frac{1}{5}$ & 0 & 0 & $\frac{4}{5}$ & 0 & $-\frac{4}{5}$ & 0 & 26 & $\frac{65}{2}$ \\
\hline & $z_{j}$ & 15 & 16 & $\frac{16}{5}$ & 0 & 0 & $-\frac{11}{5}$ & 0 & $\frac{11}{5}$ & 0 & & \\
\hline & $c_{j}-z_{j}$ & 0 & 0 & $\begin{array}{l}5 \\
-\frac{16}{5}\end{array}$ & 0 & 0 & $\begin{array}{c}5 \\
\frac{11}{5}\end{array}$ & 0 & $\begin{array}{c}5 \\
-M+ \\
\frac{11}{5}\end{array}$ & $-M$ & 716 & \\
\hline 0 & $x_{7}$ & 0 & 0 & 5 & 0 & -4 & 0 & 1 & 0 & -1 & 7 & $\frac{7}{5}$ \\
\hline 0 & $x_{4}$ & 0 & 0 & 10 & 1 & -9 & 0 & 0 & 0 & 0 & 7 & $\frac{7}{10}$ \\
\hline 0 & $x_{6}$ & 0 & 0 & -6 & 0 & 5 & 1 & 0 & -1 & 0 & 5 & - \\
\hline 15 & $x_{1}$ & 1 & 0 & -6 & 0 & 5 & 0 & 0 & 0 & 0 & 25 & - \\
\hline \multirow[t]{3}{*}{16} & $x_{2}$ & 0 & 1 & 5 & 0 & -4 & 0 & 0 & 0 & 0 & 22 & $\frac{22}{5}$ \\
\hline & $z_{j}$ & 15 & 16 & -10 & 0 & 11 & 0 & 0 & 0 & 0 & & \\
\hline & $c_{j}-z_{j}$ & 0 & 0 & 10 & 0 & -11 & 0 & 0 & $-M$ & $-M$ & 727 & \\
\hline 0 & $x_{7}$ & 0 & 0 & 0 & $-\frac{1}{2}$ & $\frac{1}{2}$ & 0 & 1 & 0 & -1 & $\frac{7}{2}$ & \\
\hline 0 & $x_{3}$ & 0 & 0 & 1 & $\frac{1}{10}$ & $-\frac{9}{10}$ & 0 & 0 & 0 & 0 & $\frac{7}{10}$ & \\
\hline 0 & $x_{6}$ & 0 & 0 & 0 & $\frac{3}{5}$ & $-\frac{2}{5}$ & 1 & 0 & -1 & 0 & $\frac{46}{5}$ & \\
\hline 15 & $x_{1}$ & 1 & 0 & 0 & $\frac{3}{5}$ & $-\frac{2}{5}$ & 0 & 0 & 0 & 0 & $\frac{146}{5}$ & \\
\hline \multirow[t]{3}{*}{16} & $x_{2}$ & 0 & 1 & 0 & $-\frac{1}{2}$ & $\frac{1}{2}$ & 0 & 0 & 0 & 0 & $\frac{37}{2}$ & \\
\hline & $z_{j}$ & 15 & 16 & 0 & 1 & 2 & 0 & 0 & 0 & 0 & & \\
\hline & $c_{j}-z_{j}$ & 0 & 0 & 0 & -1 & -2 & 0 & 0 & $-M$ & $-M$ & 734 & \\
\hline
\end{tabular}

\section{Program-2}

The equation is in accordance with Table 4 by ignoring the pseudo variables and adding the additional constraints, then the standard simplex form is obtained as follows.

Maximize :

$$
z=15 x_{1}+16 x_{2}+0 x_{3}+0 x_{4}+0 x_{5}+
$$$$
0 x_{6}+0 x_{7}+0 x_{8}-M x_{9} \text { (Thousands) }
$$

Constraints :

$$
\begin{aligned}
& -\frac{1}{2} x_{4}+\frac{1}{2} x_{5}+x_{7}=\frac{7}{2} \\
& x_{3}+\frac{1}{10} x_{4}-\frac{9}{10} x_{5}=\frac{7}{10} \\
& \frac{3}{5} x_{4}-\frac{2}{5} x_{5}+x_{6}=\frac{46}{5} \\
& x_{1}+\frac{3}{5} x_{4}-\frac{2}{5} x_{5}=\frac{146}{5}
\end{aligned}
$$


Desimal, 4 (1), 2021 - 62

Fery Firmansah, Fitriana Wulandari

$x_{2}-\frac{1}{2} x_{4}+\frac{1}{2} x_{5}=\frac{37}{2}$

$\frac{3}{5} x_{4}+\frac{3}{5} x_{5}-x_{8}+x_{9}=\frac{1}{5}$

Table 5. Simplex Solution for Program-2

\begin{tabular}{|c|c|c|c|c|c|c|c|c|c|c|c|c|}
\hline$\left(c_{B}\right)_{i}$ & $\begin{array}{c}c_{j} \\
x_{j} \\
\left(x_{B}\right)_{i}\end{array}$ & $\begin{array}{l}15 \\
x_{1}\end{array}$ & $\begin{array}{l}16 \\
x_{2}\end{array}$ & $\begin{array}{r}0 \\
x_{3}\end{array}$ & $\begin{array}{r}0 \\
x_{4}\end{array}$ & $\begin{array}{r}0 \\
x_{5}\end{array}$ & $\begin{array}{r}0 \\
x_{6}\end{array}$ & $\begin{array}{r}0 \\
x_{7}\end{array}$ & $\begin{array}{r}0 \\
x_{8}\end{array}$ & $\begin{array}{c}-M \\
x_{9}\end{array}$ & $b_{i}$ & $\boldsymbol{\theta}$ \\
\hline 0 & $x_{7}$ & 0 & 0 & 0 & \multirow{6}{*}{$\begin{array}{c}-\frac{1}{2} \\
\frac{1}{10} \\
\frac{3}{5} \\
\frac{3}{5} \\
-\frac{1}{2} \\
\frac{3}{5}\end{array}$} & \multirow{6}{*}{$\begin{array}{l}\frac{1}{2} \\
-\frac{9}{10} \\
-\frac{2}{5} \\
-\frac{2}{5} \\
\frac{1}{2} \\
\frac{3}{5}\end{array}$} & 0 & 1 & 0 & 0 & \multirow{6}{*}{$\begin{array}{l}\frac{7}{2} \\
\frac{7}{10} \\
\frac{46}{5} \\
\frac{146}{5} \\
\frac{37}{2} \\
\frac{1}{5}\end{array}$} & \multirow{16}{*}{$\begin{array}{c}- \\
7 \\
\frac{46}{3} \\
\frac{146}{3} \\
- \\
\frac{1}{3}\end{array}$} \\
\hline 0 & $x_{3}$ & 0 & 0 & 1 & & & 0 & 0 & 0 & 0 & & \\
\hline 0 & $x_{6}$ & 0 & 0 & 0 & & & 1 & 0 & 0 & 0 & & \\
\hline 15 & $x_{1}$ & 1 & 0 & 0 & & & 0 & 0 & 0 & 0 & & \\
\hline 16 & $x_{2}$ & 0 & 1 & 0 & & & 0 & 0 & 0 & 0 & & \\
\hline$-M$ & $x_{9}$ & 0 & 0 & 0 & & & 0 & 0 & -1 & 1 & & \\
\hline & $z_{j}$ & 15 & 16 & 0 & $\frac{-}{\frac{3}{5}} M+1$ & $\frac{-}{5} \overline{5}-2$ & 0 & 0 & 0 & 0 & \multirow{2}{*}{$\frac{1}{5} M+734$} & \\
\hline & $c_{j}-z_{j}$ & 0 & 0 & 0 & $\frac{3}{5} M-1$ & $\frac{3}{5} M-2$ & 0 & 0 & $-M$ & 0 & & \\
\hline 0 & $x_{7}$ & 0 & 0 & 0 & 0 & 1 & 0 & 1 & $-\frac{5}{6}$ & $\frac{5}{6}$ & $\frac{11}{3}$ & \\
\hline 0 & $x_{3}$ & 0 & 0 & 1 & 0 & -1 & 0 & 0 & $\frac{1}{6}$ & $-\frac{1}{6}$ & $\frac{2}{3}$ & \\
\hline 0 & $x_{6}$ & 0 & 0 & 0 & 0 & -1 & 1 & 0 & 1 & -1 & 9 & \\
\hline 15 & $x_{1}$ & 1 & 0 & 0 & 0 & -1 & 0 & 0 & 1 & -1 & 29 & \\
\hline 16 & $x_{2}$ & 0 & 1 & 0 & 0 & 1 & 0 & 0 & $-\frac{5}{6}$ & $\frac{5}{6}$ & $\frac{56}{3}$ & \\
\hline \multirow[t]{3}{*}{0} & $x_{4}$ & 0 & 0 & 0 & 1 & 1 & 0 & 0 & \multirow{3}{*}{$\begin{array}{l}-\frac{-}{3} \\
\frac{5}{3} \\
-\frac{5}{3}\end{array}$} & $\frac{5}{3}$ & $\frac{1}{3}$ & \\
\hline & $z_{j}$ & 15 & 16 & 0 & 0 & 1 & 0 & 0 & & $-\frac{5}{3}$ & \multirow{2}{*}{$\frac{2201}{3}$} & \\
\hline & $c_{j}-z_{j}$ & 0 & 0 & 0 & 0 & -1 & 0 & 0 & & $-M-\frac{5}{3}$ & & \\
\hline
\end{tabular}

By calculating the simplex method in Table 5, it is obtained the solution of $x_{1}=$ 29 and $x_{2}=\frac{56}{3}=18,67$ with a value of $z=$ $\frac{2201}{3}=733,67 \quad$ (Thousands). Since the result is not an integer yet, then choose any optimal simplex row in the column on the right side that containing the fraction. Then add the constraint $\frac{1}{6} x_{8} \geq \frac{2}{3}$ into the next program. If it is interpreted geometrically using substitution and elimination, the constraint $\frac{1}{6} x_{8} \geq \frac{2}{3}$ will be equal to $x_{1}+x_{2} \leq 47$.

\section{Program-3}

The equation is in accordance with Table 5 by ignoring the pseudo variables and adding the additional constraints, then the standard simplex form is obtained as follows.

Maximize :

$z=15 x_{1}+16 x_{2}+0 x_{3}+0 x_{4}+0 x_{5}+$ $0 x_{6}+0 x_{7}+0 x_{8}+0 x_{9}-M x_{10}$

(Thousands)

Constraints :

$x_{5}+x_{7}-\frac{5}{6} x_{8}=\frac{11}{3}$

$x_{3}-x_{5}+\frac{1}{6} x_{8}=\frac{2}{3}$

$-x_{5}+x_{6}+x_{7}=9$

$x_{1}-x_{5}+x_{8}=29$

$x_{2}+x_{5}-\frac{5}{6} x_{8}=\frac{56}{3}$

$x_{4}+x_{5}-\frac{5}{3} x_{8}=\frac{1}{3}$

$\frac{1}{6} x_{8}-x_{9}+x_{10}=\frac{2}{3}$ 
Desimal, 4 (1), 2021 - 63

Fery Firmansah, Fitriana Wulandari

Table 6. Simplex Solution for Program-3

\begin{tabular}{|c|c|c|c|c|c|c|c|c|c|c|c|c|c|}
\hline$\left(c_{B}\right)_{i}$ & ${ }^{c_{j}}{ }^{x_{j}}$ & $\begin{array}{l}15 \\
x_{1}\end{array}$ & $\begin{array}{l}16 \\
x_{2}\end{array}$ & $\begin{array}{r}0 \\
x_{3}\end{array}$ & $\begin{array}{r}0 \\
x_{4}\end{array}$ & $\begin{array}{r}0 \\
x_{5}\end{array}$ & $\begin{array}{r}0 \\
x_{6}\end{array}$ & $\begin{array}{l}0 \\
x_{7}\end{array}$ & $\begin{array}{r}0 \\
x_{8}\end{array}$ & $\begin{array}{r}0 \\
x_{9}\end{array}$ & $\begin{array}{l}-M \\
x_{10}\end{array}$ & $\boldsymbol{b}_{i}$ & $\boldsymbol{\theta}$ \\
\hline 0 & $x_{7}$ & 0 & 0 & 0 & 0 & 1 & 0 & 1 & $-\frac{5}{6}$ & 0 & 0 & $\frac{11}{3}$ & - \\
\hline 0 & $x_{3}$ & 0 & 0 & 1 & 0 & -1 & 0 & 0 & $\frac{1}{6}$ & 0 & 0 & $\frac{2}{3}$ & 4 \\
\hline 0 & $x_{6}$ & 0 & 0 & 0 & 0 & -1 & 1 & 0 & 1 & 0 & 0 & 9 & 9 \\
\hline 15 & $x_{1}$ & 1 & 0 & 0 & 0 & -1 & 0 & 0 & 1 & 0 & 0 & 29 & 29 \\
\hline 16 & $x_{2}$ & 0 & 1 & 0 & 0 & 1 & 0 & 0 & $-\frac{5}{6}$ & 0 & 0 & $\frac{56}{3}$ & - \\
\hline 0 & $x_{4}$ & 0 & 0 & 0 & 1 & 1 & 0 & 0 & $-\frac{5}{3}$ & 0 & 0 & $\frac{1}{3}$ & - \\
\hline \multirow[t]{3}{*}{$-M$} & $x_{9}$ & 0 & 0 & 0 & 0 & 0 & 0 & 0 & $\frac{1}{6}$ & -1 & 1 & $\frac{2}{3}$ & 4 \\
\hline & $z_{j}$ & 15 & 16 & 0 & 0 & 1 & 0 & 0 & $-\frac{1}{6} M+\frac{5}{3}$ & $M$ & $-M$ & $-\frac{2}{3} M+$ & \\
\hline & $c_{j}-z_{j}$ & 0 & 0 & 0 & 0 & -1 & 0 & 0 & $\frac{1}{6} M-\frac{5}{3}$ & $-M$ & 0 & $\frac{2201}{3}$ & \\
\hline 0 & $x_{7}$ & 0 & 0 & 0 & 0 & 1 & 0 & 1 & 0 & -5 & 5 & 7 & \\
\hline 0 & $x_{3}$ & 0 & 0 & 1 & 0 & -1 & 0 & 0 & 0 & 1 & -1 & 0 & \\
\hline 0 & $x_{6}$ & 0 & 0 & 0 & 0 & -1 & 1 & 0 & 0 & 6 & -6 & 5 & \\
\hline 15 & $x_{1}$ & 1 & 0 & 0 & 0 & -1 & 0 & 0 & 0 & 6 & -6 & 25 & \\
\hline 16 & $x_{2}$ & 0 & 1 & 0 & 0 & 1 & 0 & 0 & 0 & -5 & 5 & 22 & \\
\hline 0 & $x_{4}$ & 0 & 0 & 0 & 1 & 1 & 0 & 0 & 0 & -10 & 10 & 7 & \\
\hline \multirow[t]{3}{*}{0} & $x_{8}$ & 0 & 0 & 0 & 0 & 0 & 0 & 0 & 1 & -6 & 6 & 4 & \\
\hline & $z_{j}$ & 15 & 16 & 0 & 0 & 1 & 0 & 0 & 0 & 10 & -10 & 727 & \\
\hline & $c_{j}-z_{j}$ & 0 & 0 & 0 & 0 & -1 & 0 & 0 & 0 & -10 & $-M+10$ & 121 & \\
\hline
\end{tabular}

By calculating the simplex method in Table 6, it is obtained the solution of $x_{1}=25$ and $x_{2}=22$ with a value of $z=$
727 (Thousands). Because the solution has been obtained in the form of an integer, the process is complete.

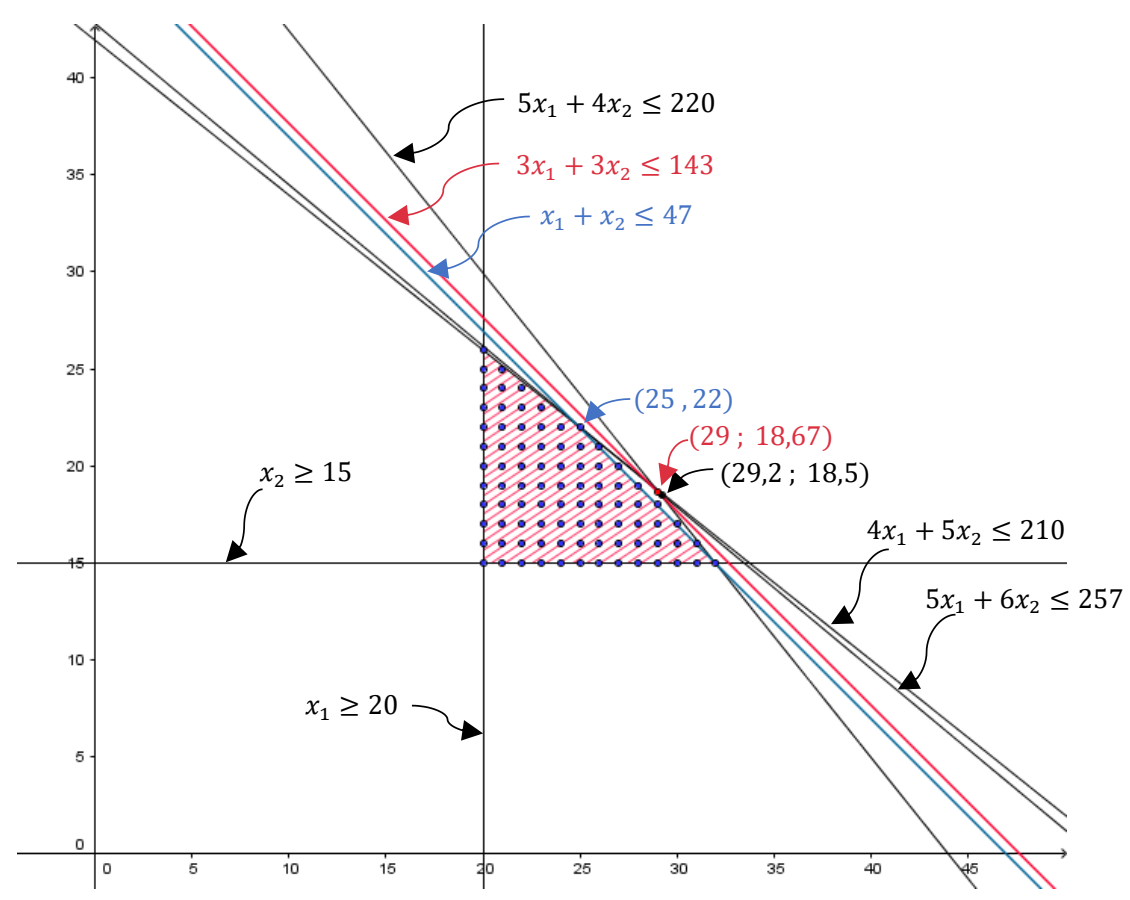

Figure 1. The Solution of The Optimization of Jenang Production 
Desimal, 4 (1), 2021 - 64

Fery Firmansah, Fitriana Wulandari

Remarks:

Figure 1 shows that the initial optimal point is $(29,2 ; 18,5)$ with a value of $z=734$. Then with the addition of the constraints $3 x_{1}+3 x_{2} \leq 143$, the optimal point obtained is $(29 ; 18,67)$ with a value of $z=733,67$. And with the addition of the constraints $x_{1}+x_{2} \leq 47$ the optimal point obtained is $(25,22)$ with a value of $z=$ 727.

The decision variables obtained are integers. So, the optimal amount of the production and the amount of profit obtained can be found. The decision variables obtained from calculations using the cutting plane method are $x_{1}=25$ and $x_{2}=22$ with a value of $z=727$ (Thousands). Thus, the optimal amount of production per day for Berkah Rasa is 25 $\mathrm{kg}$ of Jenang Ayu and $22 \mathrm{~kg}$ of Jenang Krasikan with a maximum profit of IDR 727,000 per day.

The results of this research are in line with the wishes of Berkah Rasa home industry, that is to get the right strategy in producing Jenang every day with the goal of obtaining maximum profit.

\section{CONCLUSIONS AND SUGGESTIONS}

The application of the cutting plane method in completing the optimization of production planning at Berkah Rasa is carried out by modeling the objective functions and constraints obtained from the raw material data and the number of requests. Based on the calculation using the cutting plane method, the optimal solution for Berkah Rasa is by producing $25 \mathrm{~kg}$ of Jenang Ayu and $22 \mathrm{~kg}$ of Jenang Krasikan every day. So that the benefits obtained by Berkah Rasa are IDR $727,000.00$ per day.

Based on the results of this research, the application of industrial sector in the form of food processing is obtained. Then this research can be developed on the other sector of application besides the home industry sector.

\section{REFERENCES}

Alfian, A. (2019). Model integer programming untuk mengoptimalkan perencanaan produksi di UKM "X." Jurnal Ilmiah Teknik Industri, 7(2). https://doi.org/10.24912/jitiuntar.v $7 \mathrm{i} 2.5933$

Aminudin. (2005). Prinsip-prinsip riset operasi. Erlangga.

Basriati, S. (2018). Integer linear programming pengan pendekatan metode cutting plane dan branch and bound untuk optimasi produksi tahu. Jurnal Sains Matematika Dan Statistika, 4(2).

Basriati, S., Andiraja, N., \& Rahma, A. N. (2018). Penggunaan metode cutting plane dalam menentukan solusi integer linear programming (studi kasus: Dinas perikanan pemerintah kabupaten kampar). Sntiki -10, November, 741-747.

Dey, S. S., \& Richard, J. P. (2009). Linearprogramming-based lifting and its application to primal cutting-plane algorithms. INFORMS Journal on Computing, 21(1). https://doi.org/10.1287/ijoc.1080.0 284

Nico, Iryanto, \& Tarigan, G. (2014). Aplikasi metode cutting plane dalam optimasi jumlah produksi tahunan pada PT. XYZ. Saintia Matematika, 2(2).

Pätzold, J., \& Schöbel, A. (2020). Approximate cutting plane approaches for exact solutions to robust optimization problems. European Journal of Operational Research, 284(1). https://doi.org/10.1016/j.ejor.2019. 11.059

Siagian, P. (2006). Penelitian operasional. Universitas Indonesia Press. 
Desimal, 4 (1), 2021 - 65

Fery Firmansah, Fitriana Wulandari

Siang, J. J. (2011). Riset operasi dalam pendekatan algoritmis. Andi

Publisher.

Sitorus, P. (1997). Program linier.

Universitas Trisakti. 